\title{
Study on the Use and Composition of Bio-Charcoal Briquettes Made of Organic Waste
}

\author{
Elanda Fikri', Citra Sartika²
}

1 Department of Environmental Health, Bandung Health Polytechnic, Cimahi Utara, 40514, Doctorate Program of Environmental Studies, Diponegoro University, Semarang, 50241, Indonesia

2 Department of Environmental Health, Bandung Health Polytechnic, Cimahi Utara, 40514, Indonesia

* Corresponding author's e-mail: elandafikri@yahoo.com

\begin{abstract}
The purpose of this research is to identify the ideal composition of bio-charcoal briquette made of organic waste on heat production. The employed method involved an experiment with a sample briquette with the weight of 120 g obtained using a simple random sampling technique, consisting of 4 treatments with 5 repetitions, i.e. treatment 1 (50\% leaf: 40\% twig: 10\% paper), treatment 2 (60\% leaf: $30 \%$ twig: $10 \%$ paper), treatment 3 (70\% leaf: $20 \%$ twig: $10 \%$ paper), treatment 4 (80\% leaf: $10 \%$ twig: $10 \%$ paper). The results showed that there was different composition variety of organic waste forming the briquette on the heat value ( $\mathrm{p}$ value $=0.001 \leq 0.05$ ). Organic waste composition that was most effective in making bio-charcoal briquettes was in the treatment 1 with briquette's heat value was $4.632 \mathrm{cal} / \mathrm{g}-5101 \mathrm{cal} / \mathrm{g}$, with initial temperature of $28^{\circ} \mathrm{C}$ and final temperature of $85^{\circ} \mathrm{C}$ and time length needed to become ash was 67 minutes.
\end{abstract}

Keywords: bio-charcoal briquettes, heat value, temperature, time length, composition, organic waste.

\section{INTRODUCTION}

Many industries have not maximized their waste sector potency (Fikri et al., 2016), especially organic waste. PT. Asia Pacific Fibers (PT. APF) located in Karawang Indonesia has an area of 50 ha with an open area of $\pm 25 \mathrm{Ha}$ (APF, 2017).

On the basis of the data from PT.APF, the waste generated from PT. APF was derived from industrial production activities, office activities, and nature (falling leaves, twigs in industrial areas). Data observed for 8 days, the waste generation at PT. APF was as high as $4.9 \mathrm{~m}^{3} /$ day, weighing $193.33 \mathrm{~kg}$ /day (APF, 2017). The concept of waste processing that is still used by PT APF is the old paradigm with the end-of-pipe approach that is to manage waste with the collecting transporting - casting off (Fikri et al., 2015).

Briquette is a solid produced through the process of forging and pressurizing and if burned, it will produce a small amount of smoke. Charcoal briquette or bio-charcoal is charcoal processed with a pressing system using adhesive, so that a briquette -shape can be obtained for use. Briquettes have an economical advantage because they can be produced in a simple process, have high heat value, and the raw materials are readily-available in the industry, enabling to compete with other fuels (Rafsanjani et al., 2012).

An important factor in briquette production is to pay attention to the material composition, since it will affect the absorption of water content, ash content, and the quality of resulting heat value (Thoha et al., 2010). Heat value is a fuel property that expresses the energy content of the fuel. Heat value of a fuel can be determined by testing and estimating, based on the composition. Determination of the heat value also enables to identify the burning heat value of a material. The heat value of a material is influenced by water and ash contents and closely related to fixed carbon content. Low levels of water and ash contents will 
increase the heat value of a material. On the other hand, high levels of fixed carbon in the material will increase the heat value.

\section{MATERIAL AND METHODS}

The design used in this study was an experiment with Post-test Without Control research design (Sugiyono, 2009). The utilized sample involved making variation of organic waste composition (leaves, twigs, papers) and then testing the heat value on the briquette. Some of the controlled variables in this study were:

\section{Sample design}

The sample design was randomized sampling, which is part of the organic waste generated by PT APF. The sample size was adjusted to the number of treatments, i.e. 4 treatments with 5 repetitions (Gomez, 2007). Therefore, the total mass of organic charcoal waste used was 2000 grams and total starch used was $20 \%$ of the total volume of organic charcoal waste (400 grams). The following table compares the sample number from each composition of organic waste:

\section{Data collecting tools and research procedures} are:

The tools used in collecting the research data

a) Scales to measure the weight of organic waste, starch, and briquettes. b) Calorimeter bomb to measure the heat value of briquettes.

c) Firing temperature thermometer to measure the temperature of the briquettes and the banding process.

d) Mercury thermometer to measure the temperature of the cooking water using briquettes.

The research procedure began with process of carbonization of organic waste materials (leaves, twigs, papers) which were turned into charcoal and then poured and sieved using 40 mesh size. The next step was to make briquette dough based on the briquette composition in which the heat value had been determined and tested by ASTM D 5856 method (BSN, 2000).

\section{RESULTS AND DISCUSSION}

\section{Briquette heat value}

The data in Table 3 shows that the heat value of briquettes has fluctuated. The lowest heat value was found on the organic waste composition of 80\% Leaves: $10 \%$ Twigs: $10 \%$ Paper, which equals to $4632 \mathrm{cal} / \mathrm{g}$, while the highest heat value of briquettes was found in the organic waste composition of 50\% Leaves: $40 \%$ Twig: $10 \% 5101 \mathrm{cal} / \mathrm{g}$ and with an average heat value of $4881.40 \mathrm{cal} / \mathrm{g}$.

\section{Thermal process temperature}

On the basis of the results from burning the organic waste into charcoal and carbonization

Table 1. Confounding variables of and the control

\begin{tabular}{|c|l|l|}
\hline No & \multicolumn{1}{|c|}{ Confounding variables } & \multicolumn{1}{c|}{ Control of the confounding variables } \\
\hline 1 & Various types of leaves, twigs, papers & Dry when sorting of various types of organic waste materials \\
\hline 2 & Carbonization process & $\begin{array}{l}\text { During the carbonization, it should be kept in the absence of air with } \\
\text { temperatures above } 150^{\circ} \mathrm{C}\end{array}$ \\
\hline 3 & Briquette shape & Cylindrical briquettes and adjusted with press tools \\
\hline 4 & Various types of starch & Use type starch made of flour \\
\hline 5 & Type of briquatte & Use a fine briquette type with 40 mesh sieving \\
\hline
\end{tabular}

Table 2. Comparison of organic waste samples composing briquette

\begin{tabular}{|c|c|c|c|c|c|c|c|c|c|}
\hline Treatment & Daun, \% & Leaf, g & Twig, \% & Twig, g & Paper, \% & Paper, g & $\begin{array}{c}\text { Charcoal } \\
\text { weight, } g\end{array}$ & $\begin{array}{c}\text { Total of starch } \\
\text { flour, g }\end{array}$ & Total of treatment, g \\
\hline LTP 1 & 50 & 50 & 40 & 40 & 10 & 10 & 100 & 20 & 600 \\
\hline LTP 2 & 60 & 60 & 30 & 30 & 10 & 10 & 100 & 20 & 600 \\
\hline LTP 3 & 70 & 70 & 20 & 20 & 10 & 10 & 100 & 20 & 600 \\
\hline LTP 4 & 80 & 80 & 10 & 10 & 10 & 10 & 100 & 20 & 600 \\
\hline \multicolumn{8}{|c|}{ Total } \\
\hline
\end{tabular}

Notes: LTP - leaves, twigs, papers. 


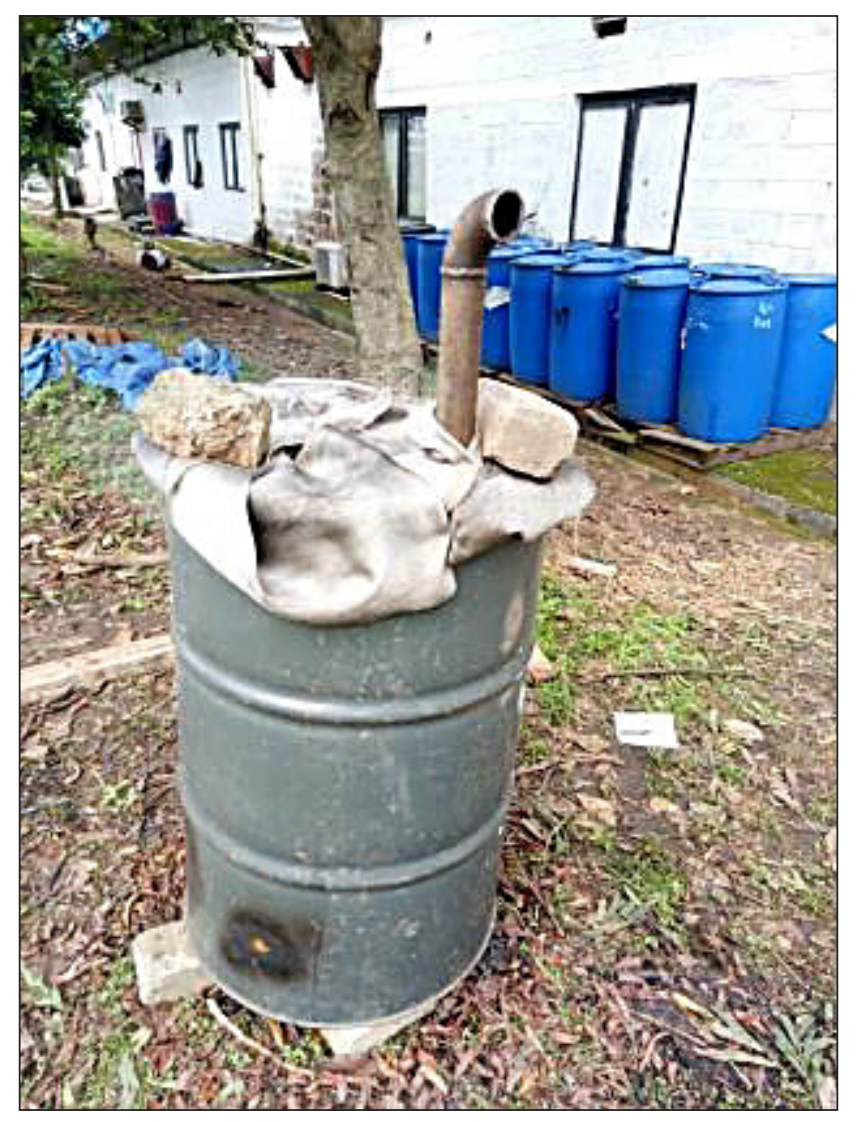

Figure 1. Organic waste carbonization process

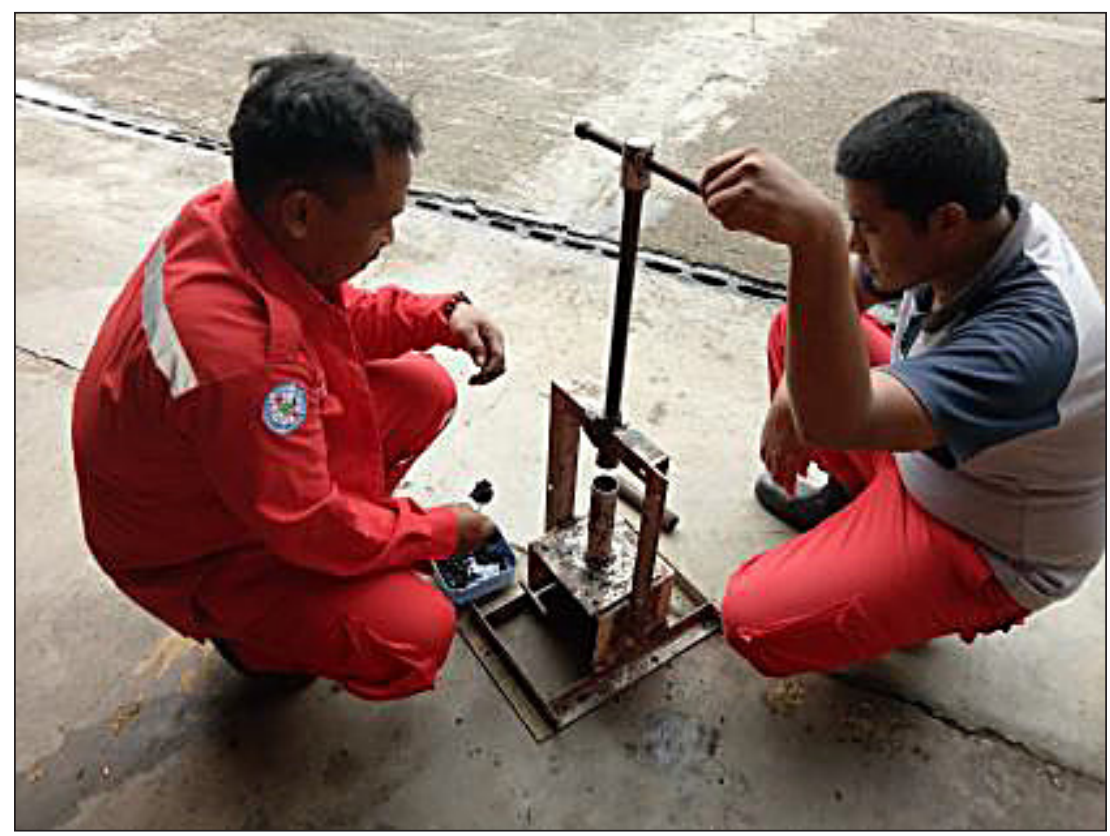

Figure 2. Pressing briquettes with pressing tool

carried outfor 8 hours, it was fund that the minimum temperature value was $143^{\circ} \mathrm{C}$ for burning leaves, and the maximum temperature was $220^{\circ} \mathrm{C}$ in the case of burning twigs, with the average temperature ranging from $162.22^{\circ} \mathrm{C}$ to $199.67^{\circ} \mathrm{C}$
(Table 4). This shows the difference in the temperature of carbonization process in the drum due to the difference in the type of material used in the carbonization process. Another research conducted by Pari et al. (2013) in the experimental 


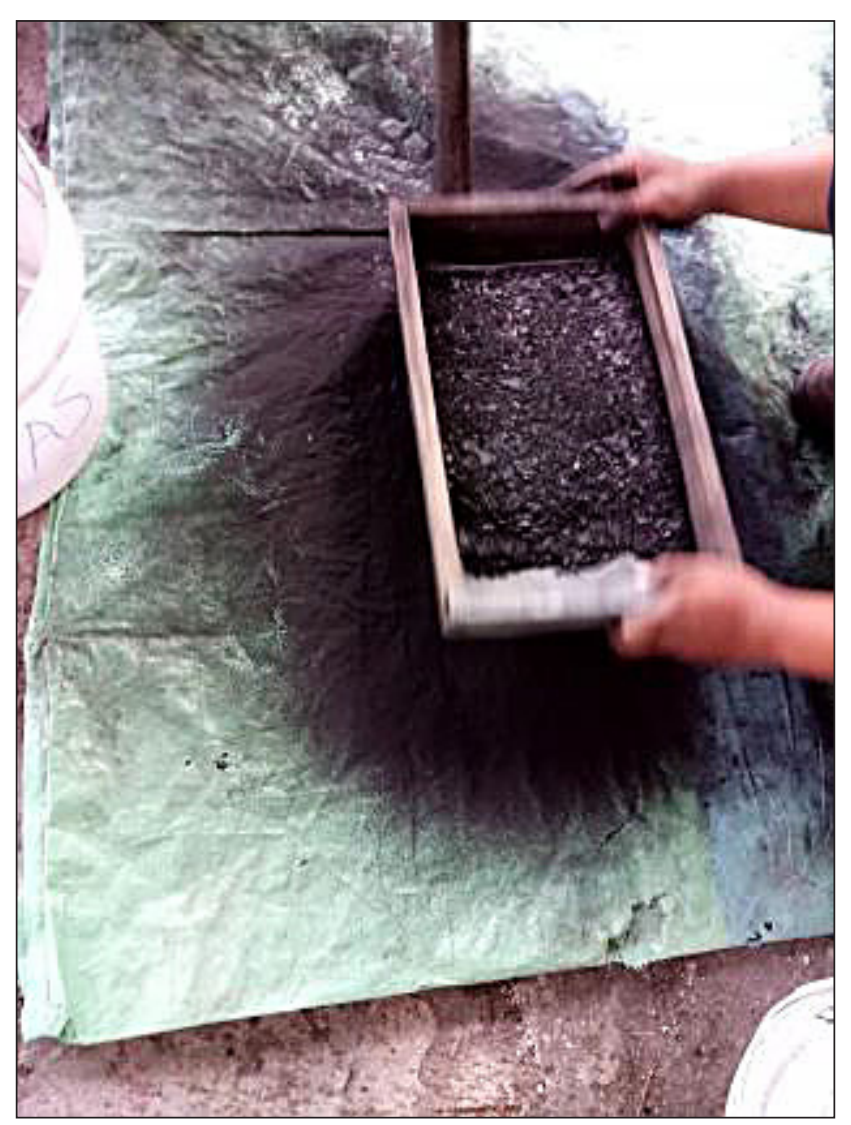

Figure 3. Charcoal sieving with 40 mesh size

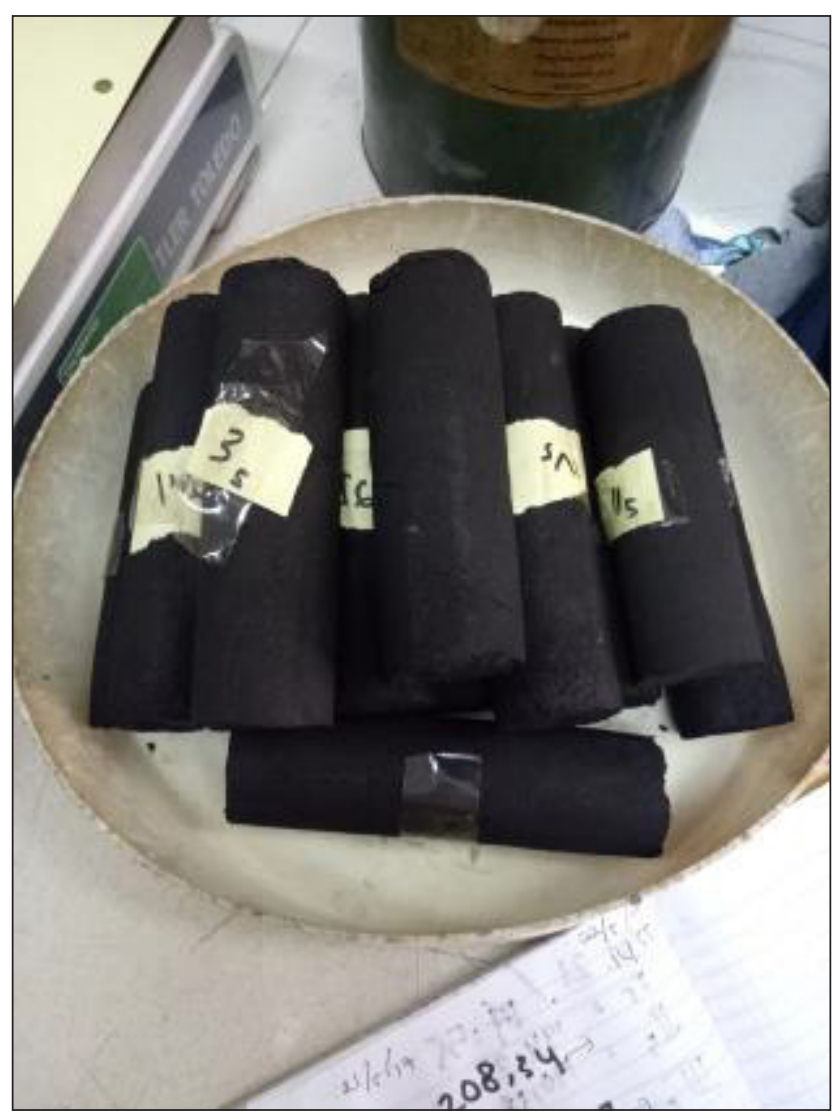

Figure 4. Bio-charcoal briquettes 
Table 3. Briquette heat value

\begin{tabular}{|c|c|c|c|c|c|}
\hline Variable (\%) & $\mathrm{N}$ & Mean, cal/g & Std. Deviation & Minimum, cal/g & Maximum, cal/g \\
\hline 50L; 40T; 10P & 5 & 5055.4 & \pm 31.801 & 5022 & 5101 \\
\hline 60L; 30T; 10P & 5 & 4975.2 & \pm 32.538 & 4953 & 5032 \\
\hline 70L; 20T; 10P & 5 & 4804.6 & \pm 62.280 & 4724 & 4890 \\
\hline 80L; 10T; 10P & 5 & 4690.4 & \pm 53.910 & 4632 & 4774 \\
\hline Total & 20 & 4881.4 & \pm 152.641 & 4632 & 5101 \\
\hline
\end{tabular}

Table 4. Temperature measurement in organic waste carbonization process

\begin{tabular}{|c|c|c|c|c|c|c|}
\hline \multirow{2}{*}{ Organic waste } & \multicolumn{3}{|c|}{ Measurement, ${ }^{\circ} \mathrm{C}$} & \multirow{2}{*}{ Temperature mean, ${ }^{\circ} \mathrm{C}$} & Temperature max, ${ }^{\circ} \mathrm{C}$ & $\begin{array}{c}\text { Min temperature, } \\
{ }^{\circ} \mathrm{C}\end{array}$ \\
\cline { 2 - 7 } & $\mathrm{I}$ & $\mathrm{II}$ & $\mathrm{III}$ & 162 & 199 & 143 \\
\hline Leaf & 144 & 199 & 143 & 174 & 212 & 154 \\
\hline Paper & 156 & 212 & 154 & 200 & 220 & 185 \\
\hline Twig & 185 & 220 & 194 & & 174 \\
\hline
\end{tabular}

study on the Combination Test of Combined Coconut Milk and Coconut Shredded Fuel As an Alternative Fuel, indicates that the carbonization (pyrolysis) process is the decomposition of biomass (lysis) into heat (pyro) at the temperature over $150^{\circ} \mathrm{C}$ using different types of materials.

On the basis of the result of weighing organic waste experiment before and after becoming charcoal, it was observed that the burning shrinkage was $82.78 \%$ to $88 \%$ with percentage of becoming charcoal of $11.35 \%$ to $14.08 \%$ (Table 5). The results of research conducted by Supriyatno (2010) indicate that during the process of carbonization, the higher the heating temperature, the more time isrequired and the more non-carbon substances are reduced, resulting in smaller charcoal weight. The results of this study are strengthened by the results of the research conducted by Tirono et 1.. (2012) on the Effect of Temperature on the Carbonization Process on Coconut Shell Charcoal Heat Value, which explains that the decrease of material mass caused by heating results in material decomposition or the release of easily evaporated compounds.

According to Toha et 1.. (2010), carbonization of biomass is a process to increase the heat value of biomass and produce clean combustion with a bit smoke. Carbonization results in the formation of charcoal which is black and composed of carbon. This indicates that the lagging mass and the amount of charcoal obtained decrease as the carbonization temperature increases.

According to Supriyatno et 1.. (2010), heating leaves with high temperature will produce a low weight of charcoal because many green leaf substances are burned. During the heating of leaves using pyrolysis, the higher the temperature, the faster the combustion process. Carbonization on twigs produces less charcoal, and at the temperature of $300^{\circ} \mathrm{C}$, it requires a relatively short period of time. The resulting charcoal color is black and the charcoal becomes very soft after being smoothed.

According to Borowski et al. (2017) two types of binders were repeatedly used to produce briquettes of native wheat starch and modified wheat starch, at $8 \%$ of the whole. The combustion test showed quite different burning properties. Briquettes should be characterized by short firing up time and lower smokiness, as well as high maximum temperature and long burning time. In this research it was concluded that briquettes with native wheat starch used as a binder are more appropriate for burning in the grill.

On the basis of the results described in Figure 5 and reference to Indonesian National Standard (SNI) no. 01-6235-2000 regarding minimum qualified heat value $(5,000 \mathrm{cal} / \mathrm{g})$, treatment 1 with

Table 5. Measurement of organic burned waste

\begin{tabular}{|c|c|c|c|c|c|}
\hline Type of waste & Initial weight, $\mathrm{kg}$ & Charcoal weight, kg & Burned weight, $\mathrm{kg}$ & $\begin{array}{c}\text { Burned percentage, } \\
\%\end{array}$ & $\begin{array}{c}\text { Percentage of } \\
\text { becoming charcoal, } \\
\%\end{array}$ \\
\hline Leaf & 9.74 & 1.10 & 8.64 & 85.91 & 14.08 \\
\hline Paper & 10.60 & 1.82 & 8.77 & 82.78 & 17.21 \\
\hline Twig & 30.83 & 3.50 & 27.33 & 88.64 & 11.35 \\
\hline
\end{tabular}


5 repetitions indicates that the briquette quality with heat value meets SNI requirement in $100 \%$.

The results of various differences between organic waste composition of leaves, twigs, and papers and heat values are influenced by each composition. The composition with the highest heat value is obtained from treatment 1 that comprises 50\% Leaves: $40 \%$ Twigs: $10 \%$ Papers, the heat value at the treatment 1 is at least $5,022 \mathrm{cal} / \mathrm{g}$ and the maximum heat value is $5,101 \mathrm{cal} / \mathrm{g}$ (which meets SNI requirements). This is due to a greater share of twigs in the composition, which is in accordance with research conducted by Damanhuri et al. (2016) who explain that the heat value of twigs is $4716 \mathrm{cal} / \mathrm{g}$, heat value of leaves is 3998 $\mathrm{cal} / \mathrm{g}$, and heat value of paper is $3024 \mathrm{cal} / \mathrm{g}$. On the other hand, the research conducted by Gandhi (2010) states that the heat value of wood is greatly affected by carbon, lignin, and resin substances, while the cellulose content of wood is not so influential. Therefore, the higher the share of twig (wood) in the composition, great er the value of the resulting heat .

\section{Bivariate test results}

On the basis of the analysis results using one way Anova, the obtained $\mathrm{F}$ value is 61.323 and $\mathrm{P}$ value is $0.001(\alpha=0,05)$ (Table 6). This shows that there is a difference between various compo- sition of organic waste composing briquette and the heat value briquettes produced.

The comparisons of Post Hoc test results indicate that $\mathrm{p}$-value was $<0.05$ in all treatments, so it can be assumed there are differences in all treatments (Table 7). The largest mean difference value is in the treatment 1 compared to the other treatments, meaning that the treatment 1 gives the greatest effect.

\section{Briquette usage try outs}

On the basis of the briquette usage for boiling water in the pan, it was fund that the briquette 1 indicates a temperature of $450^{\circ} \mathrm{C}$, briquette 2 indicates a temperature of $419^{\circ} \mathrm{C}$, briquette 3 a temperature of $407^{\circ} \mathrm{C}$, and the fourth briquette showed a temperature of $401^{\circ} \mathrm{C}$ (Figure 6). Hence, the organic waste briquette that was characterized by the highest temperature was briquette 1 with heat value of $5101 \mathrm{cal} / \mathrm{g}$. The results also showed that the briquettes used in treatment 1 during water boiling had the initial temperature of $28^{\circ} \mathrm{C}$ and the final temperature was $88^{\circ} \mathrm{C}$, the briquette 2 had the initial temperature of $28^{\circ} \mathrm{C}$ and the final temperature was $82^{\circ} \mathrm{C}$, briquette 3 had initial temperature of $28^{\circ} \mathrm{C}$ and the final temperature was $85^{\circ} \mathrm{C}$, whereas the briquette 4 had initial temperature of $28^{\circ} \mathrm{C}$ and the final temperature was $79^{\circ} \mathrm{C}$. Therefore, the organic waste bri-

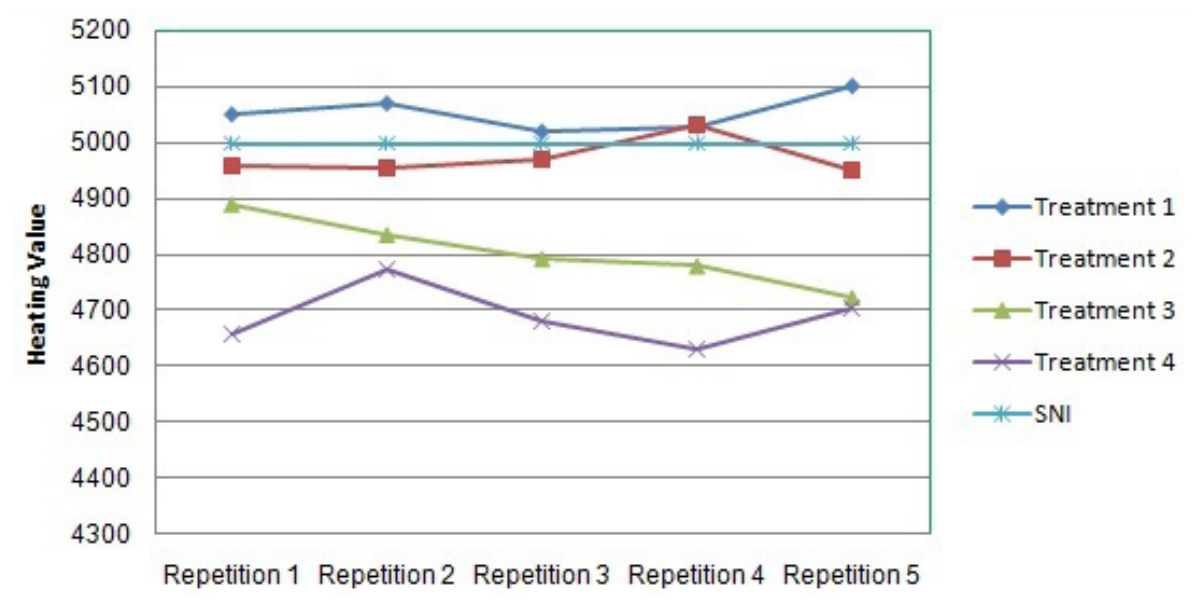

Figure 5. Briquettes with heat value meets Indonesia National Standard (SNI)

Table 6. Results of one way Anova data analysis

\begin{tabular}{|c|c|c|c|c|c|}
\hline Variable & SD & $95 \% \mathrm{Cl}$ & Min - Max & p-value & $\mathrm{F}$ \\
\hline Treatment 1 & 31.801 & $5015.91-5094.89$ & $5022-5101$ & 0.001 & 61.323 \\
\hline Treatment 2 & 32.538 & $4934.80-5015.60$ & $4953-5032$ & & \\
\hline Treatment 3 & 62.280 & $4727.27-4881.93$ & $4724-4890$ & & \\
\hline Treatment 4 & 53.910 & $4623.46-4757.34$ & $4632-4774$ & & \\
\hline
\end{tabular}


Table 7. Results of multiple comparisons Post Hoc data analysis

\begin{tabular}{|c|c|c|c|}
\hline \multicolumn{2}{|c|}{ Variable } & Mean difference & P value \\
\hline & Treatment 2 & $80.200^{*}$ & 0.016 \\
\hline & Treatment 3 & $250.800^{*}$ & 0.001 \\
\hline & Treatment 4 & $365.000^{\star}$ & 0.001 \\
\hline Treatment 2 & Treatment 1 & $-80.200^{*}$ & 0.016 \\
\hline & Treatment 3 & $170.600^{*}$ & 0.001 \\
\hline Treatment 3 & Treatment 4 & $284.800^{*}$ & 0.001 \\
\hline & Treatment 1 & $-250.800^{*}$ & 0.001 \\
\hline & Treatment 2 & $-170.600^{*}$ & 0.001 \\
\hline Treatment 4 & Treatment 4 & $114.200^{*}$ & 0.001 \\
\hline & Treatment 1 & $-365.000^{*}$ & 0.001 \\
\hline & Treatment 2 & $-284.800^{*}$ & 0.001 \\
\hline
\end{tabular}
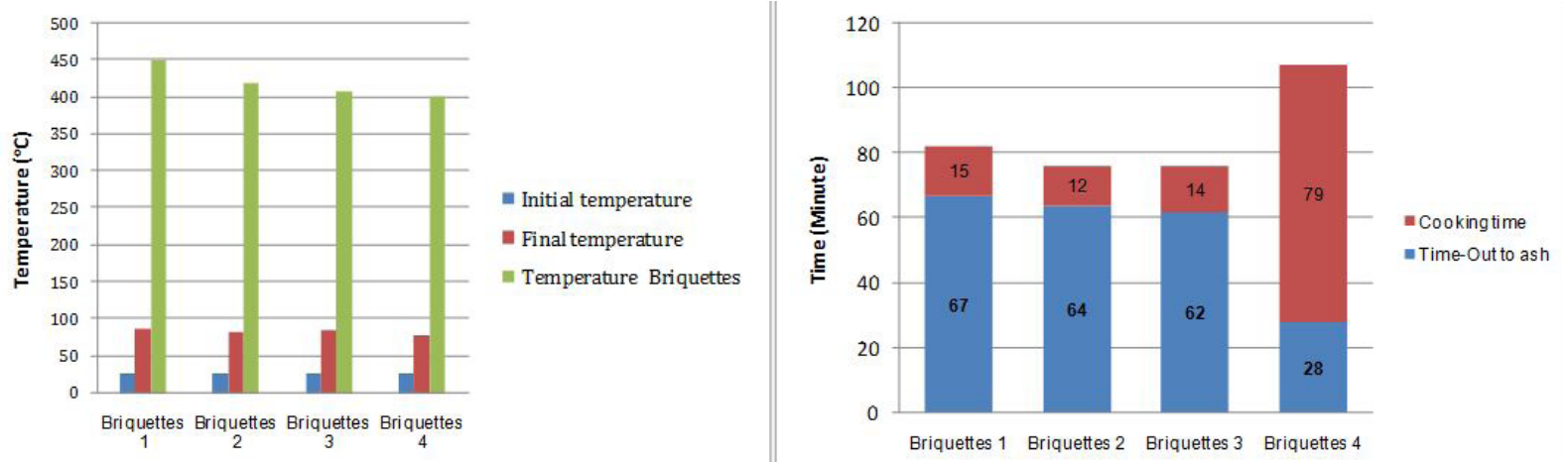

Figure 6. Temperature observation result $\left({ }^{\circ} \mathrm{C}\right)$, time (minute) during the briquette usage try outs using water boiling method

quette that had the highest temperature was briquette 1 because the composition of twig (wood) is more dominant.

The results also explain that during the boiling of water, using briquettes with a volume of $500 \mathrm{ml}$ for each aluminum pot, in the case of treatment 1 , briquette 1 could boil the water for 15 minutes while the length of time needed for the briquette turn to ashes was 67 minutes, treatment 2 for 12 minutes and was reduced to ashes after 64 minutes, treatment 3 for 14 minutes and turned to ashes after 62 minutes, and treatment 4 for 23 minutes and reduced to ashes after 93 minutes. The briquette with treatment 1 showed the best quality because of the maximum temperature that can be reached and the ideal time length needed to turn to ashes. The results of the research conducted by Arni et al. (2014) on the Study of Physical Characteristics of Bio-Charcoal Briquettes as Alternative Energy Sources investigating the physical comparison tested from the combustion of bio-charcoal briquette - indicated that the cylindrical shape enables to achieve maximum temperature, and the time required to turn into ideal ash, which is reviewed based on the combustion test.

\section{CONCLUSIONS}

1. The utilization of organic waste produced in PT.APF is used as bio-charcoal briquettes.

2 . There is a significant difference from various composition of briquette organic waste to the heat value ( $\mathrm{p}$ value $=0.001 \leq 0.05$ )

3. Composition of organic waste that is most effective in the production of charcoal briquettes is the treatment 1 with variations of $50 \%$ leaves: $40 \%$ twigs: $10 \%$ paper, with heat value of $4632 \mathrm{cal} / \mathrm{g}-5101 \mathrm{cal} / \mathrm{g}$ (corresponding to the standard value of briquette in Indonesian National Standard).

4. The results of try outs using briquettes with the boiling water show that composition 1 is characterized by the initial temperature of $28^{\circ} \mathrm{C}$ and the final temperature of $85^{\circ} \mathrm{C}$ with the time required to turn to ash amounting to 67 minutes. 


\section{Acknowledgements}

This study was financially supported by Unit Penelitian dan Pengabdian Masyarakat (UPPM) Poltekkes Kemenkes RI Bandung, Ministry of Health, Indonesia scheme.

\section{REFERENCES}

1. Arni Hosiana M.D.L., Anis N. 2014. Study of physical characteristic test of bioarang briquette as alternative energy source. Journal of Natural Science, 3(1), 89-98.

2. Borowski G., Stępniewski W., Wójcik-Oliveira K. 2017. Effect of starch binder for properties of charcoal briquettes. International Agrophysics, 31(4), 571-574.

3. Company profile Asia Pacific Fibers (APF) Karawang, 2017. PT. APF Karawang Indonesia.

4. BSN 2000. Indonesia National Standard No. 1-6235-2000 about wood charcoal briquettes. BSN, Jakarta.

5. Damanhuri E., Padmi T. 2016. Integrated Waste Management. ITB Press, Bandung.

6. Fikri E., Purwanto P., Henna R.S. 2015. Modelling of household hazardous waste (HHW) management in Semarang City (Indonesia) by using life cycle assessment (LCA) approach to reduce greenhouse gas (GHG) emissions. Procedia Environmental Science, 23(2015), 123-129.

7. Fikri E., Purwanto P., Henna R.S. 2016. Life cycle assessment of household hazardous waste manage- ment options for Semarang City, Indonesia. Int. J. Environment and Waste Management, 17(2), 146-157.

8. Gandhi A. 2010. The effect of variation on the amount of adhesive mixture on briquette characteristics. Profesional, 8(1), 1-12.

9. Gomez K.A. 2007. Statistical procedure for research. Universitas Indonesia Press, Jakarta.

10. Pari G., Mahfudin Jajuli, 2012. Charcoal making technology, charcoal briquettes and activated charcoal and its utilization. Appropriate Technology. Agency for Forestry Research and Development, Ministry of Forestry. 1-9.

11. Rafsanjani K.A., Sarwono S., Noriyanti D.R. 2012. Study of potential utilization of biomass from organic waste as alternative fuel (briquette) in support of eco-campus in ITS Surabaya. Teknik Pomits, 1(1), 1-6.

12. Sugiyono S. 2009. Quantitative and qualitative research methods. Alfabeta, Bandung.

13. Supriyatno S., Merry C, 2010. Case study of alternative energy waste campus environment campus POLBAN. Proceedings of National Seminar on Chemical Engineering “Kejuangan”. Development of Chemical Technology for Natural Resources Processing of Indonesia, 101-109.

14. Thoha Y., Diana E.F. 2010. Making charcoal briquettes from teak leaves with sago palm as a binder. Journal of Chemical Engineering Sriwijaya University, 17(1), 34-43.

15. Tirono M., Ali S. 2012. Temperature effect on the process of bleaching to the heating value of coconut shell charcoal. Neutrino, 143-152. 